\title{
Nodular Neoplasm
}

National Cancer Institute

\section{Source}

National Cancer Institute. Nodular Neoplasm. NCI Thesaurus. Code C36012.

A benign or malignant neoplasm characterized by the formation of nodules by the proliferating neoplastic cells. 